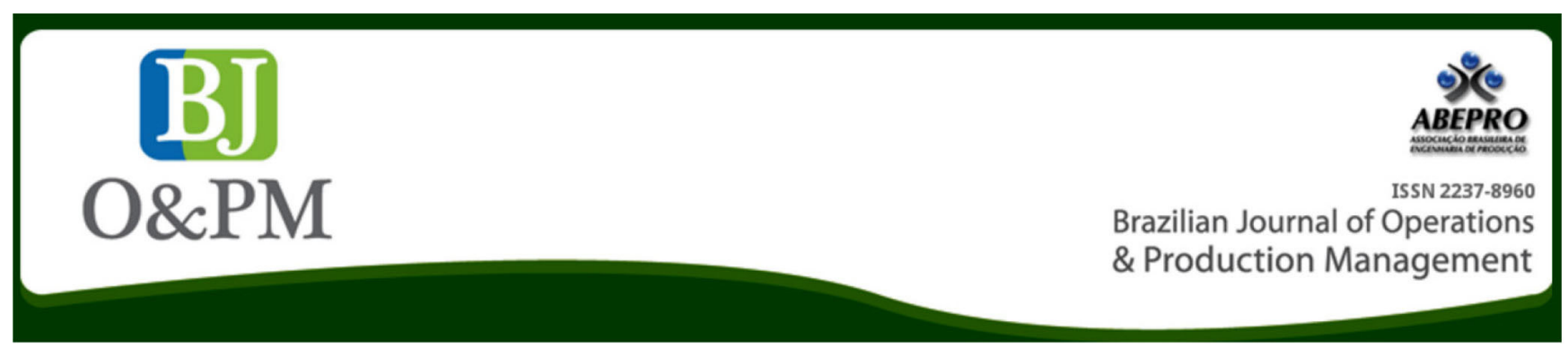

\title{
A COMPARATIVE ANALYSIS BETWEEN THE QUICK RESPONSE MANUFACTURING AND TIME-BASED COMPETITION METHODOLOGIES
}

\author{
Fábio Nogueira Emboava ${ }^{1}$, Rodolfo Cardoso ${ }^{1}$, lara Tammela ${ }^{1}$ \\ 1 Fluminense Federal University
}

\begin{abstract}
This article compares the Quick Response Manufacturing and Time-Based Competition methodologies and identifies their similarities and differences. This investigation deepens our understanding in terms of Quick Response Manufacturing pursuing a theoretical framework for applications in Brazilian companies. Data was collected from publications aimed at presenting and discussing the tactics and approaches of the methodologies. Similarity and difference classification tables are presented. The results reveal that $67 \%$ of all approaches compared were classified as analogous and $19 \%$ were not analogous. In addition, $14 \%$ of approaches presented the non-existence of similarities.
\end{abstract}

Key Words: Quick Response Manufacturing, Time-Based Competition, Lead Time 


\section{INTRODUCTION}

The Quick Response Manufacturing (QRM) methodology was developed by professor Rajan Suri in 1998 (Godinho et Veloso, 2013). Suri (1998) defines QRM as a company-wide strategy focusing on lead time reductions. In addition, QRM is a reshaping of Time-Based Competition (TBC) for manufacturing companies, establishing a new dimension of competition. According to Suri (1999), QRM means rapidly delivering customized products from an external perspective, internally reducing lead times, improving quality and lowering costs. QRM enhances the improvement programs already in place in companies, working to eliminate the dysfunctional variability caused by errors and deviations in the processes. It explores the strategic variability based on the demand variation (Suri, 2010c; 2011).

TBC was first used by George Stalk in the 1980s. At that time, it referred to a strategy based on time. Such a strategy aims to reduce the response time to customer demands through lead time reductions related to product development and the delivery cycle (Hum et Sim, 1996). Stalk et Hout (1990a) mention that a company only becomes timebased by developing superior insight into what is customer values and, once this information is collected, they build the company around it.

Stalk et Webber (1993) mention that a company passes through three stages to successfully use the time strategy. In Stage One, the management team discovers the power of time. In Stage Two, the company, as a whole, discovers the power of time to unleash the innovation. And in Stage Three, the company uses the time to serve the customers according to their needs. According to Blackburn (1992), the response time to the customer is a key competitive advantage. Stalk (1992) states that the competitive advantage is a combination of the structural positioning and the focus on building capabilities. The advantages of competition include: higher prices, a larger market share, better customer services and productivity improvements (Helms et Ettkin, 2000).

Godinho et Veloso (2013) evaluated the literature on competition based on time methodologies and their correlations. The authors draw attention to the gaps in the quantitative research. These gaps include: lack of utilization principles, lot size, performance measurements and the practical application of the concepts and principles of the methodologies. Emboava et Cardoso (2016) discussed the relationship between the concepts and principles of Lean Manufacturing, TBC and QRM (Figure 1).

Emboava et Cardoso (2016) verified that Lean Manufacturing, TBC and QRM are convergent. They then underlined the common purpose of changing the traditional model of the organizations by focusing on creating a competitive ad- vantage. The authors concluded that QRM, based on the relationship between the concepts and principles of the methodologies, is a proposal of the evolution from TBC. Its principles are grounded in Lean Manufacturing. It is aimed at reducing time, eliminating waste and increasing resource availability.

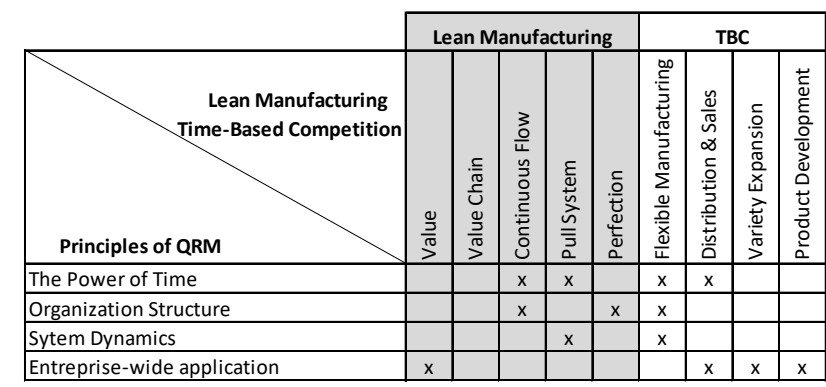

Figure 1. Relationship between the concepts and principles of lean manufacturing, time-based competition and quick response manufacturing

Source: Emboava et Cardoso (2016)

Consequently, the primary aim of this article is to compare QRM and TBC by identifying their similarities and differences in regard to the approaches used by both methodologies. This article is one part of a research project intended at deepening the understanding in terms of QRM applications in Brazilian companies that are pursuing a theoretical initial framework. The rest of this article is structured as follows:

i. Section 2 presents the research methodology;

ii. Section 3 presents the theoretical reference, the structure of the QRM tactics and their respective approaches, as well as the comparison process;

iii. Section 4 illustrates the results of the relationship between the QRM and TBC approaches, the comparison process, and the analysis of the similarity between the approaches; and

iv. Section 5 presents the conclusions and recommendations for future research.

\section{RESEARCH METHODOLOGY}

This section is aimed at presenting the methodological framework of the research process. It also provides the context. According to Kauark et al. (2010), the research type categorizes the methodological framework of the investigative strategies. Morgan et Smircich (1980) state that the methodology is related to the research objectives. Figure 2 illustrates the methodological framework of this article. 
Brazilian Journal of Operations \& Production Management Volume 14, Número 3, 2017, pp. 414-427

DOI: 10.14488/BJOPM.2017.v14.n3.a14

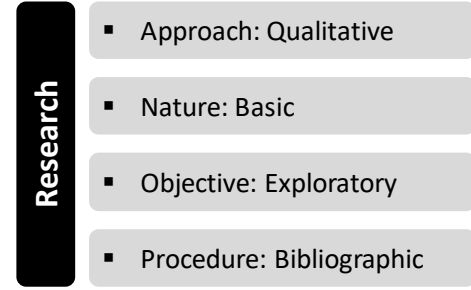

Figure 2. Methodological Framework Source: The authors own

According to Gerhardt et Silveira (2009), research can be quantitative and/or qualitative. Qualitative research is concerned with understanding the topic in question, instead of the quantity of the data. The present article is conducting a qualitative study that compares and classifies the level of similarity between QRM and TBC. This basic study is focused on increasing the knowledge on the methodologies using a theoretical analysis, without concern to create or build solutions for a specific problem and/or application.

Gil (2008) states that three classifications of objective research exist: exploratory, descriptive and explanatory. Exploratory research is based on the material already existing, such as books and scientific research. This article is an exploratory study on QRM and TBC, seeking to increase the knowledge on time-based methodologies. Data is collected from bibliographic research to compare QRM and TBC. Figure 3 presents the research process.

The research process follows five steps:

i. Step 1: Lists Rajan Suri's publications related to QRM. Conducts a database and website search using: 1. QRM and Rajan Suri's name, and 2. QRM with- out Rajan Suri's name;

ii. Step 2: Lists George Stalk's TBC publications related to TBC. Conducts a database and website search using: 1. TBC and George Stalk's name, and 2. TBC without George Stalk's name;

iii. Step 3: Structures the QRM tactics, based on the QRM publications and their respective approaches;

iv. Step 4: Tabulates the QRM tactics and their respective approaches, matching them with the TBC approaches, comparisons and classifications of similarity, based on the variables of comparison and;

v. Step 5: Presents the general classification of the similarity table and the distribution chart by similarity class.

\subsection{Bibliographic Research}

The bibliographic research was carried out on Scopus, CAPES, QRM, Google Academic and QRM Center. This article focused on the analysis of the QRM and TBC publications related to the tactics and approaches of changing companies that compete, based on the cost to companies that compete based on time. The research process of publications on TBC was initially oriented by George Stalk's publications, because he was the first to use the term TBC. The search was complemented with publications written by other authors. For the QRM publications, the research was initially oriented by Rajan Suri's publications, as he was the creator of QRM. The

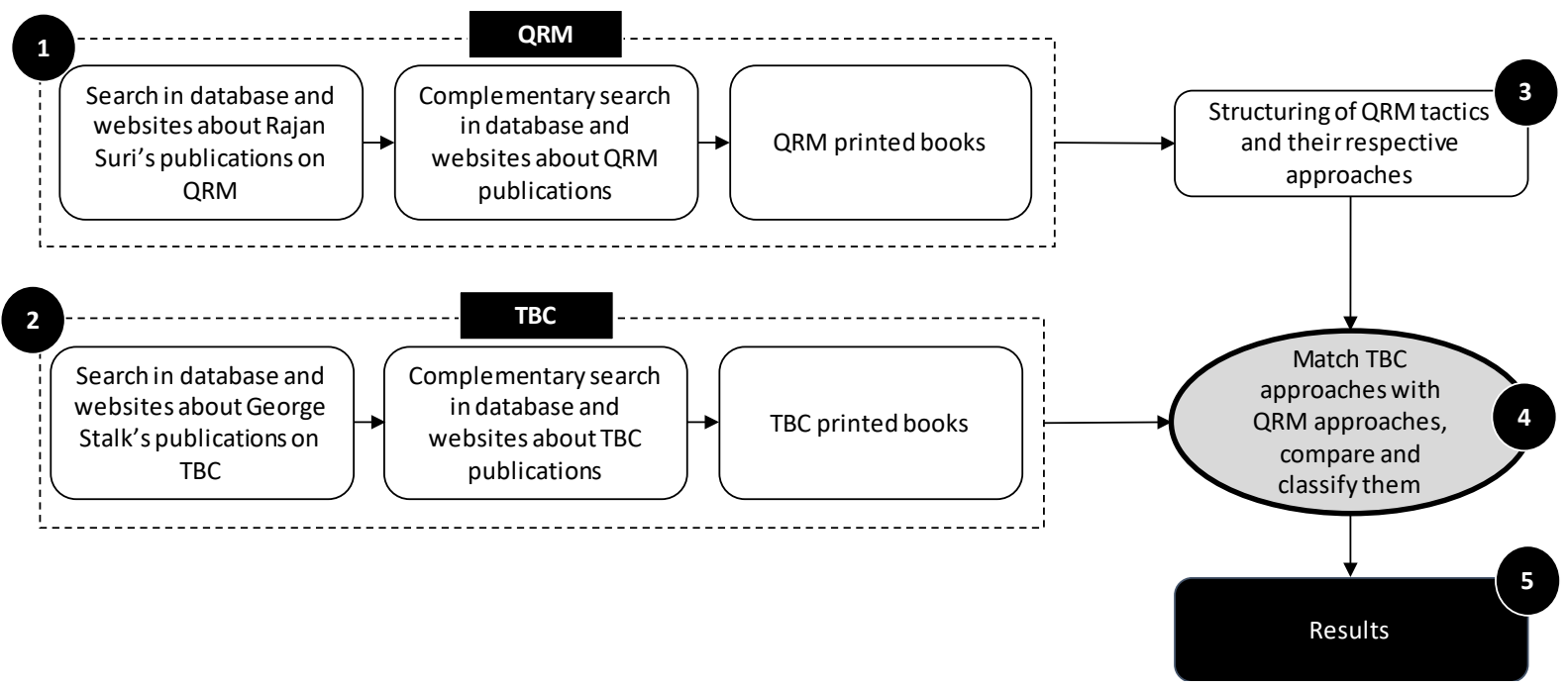

Figure 3. Research Process

Source: The authors own 
search was complemented with publications from other authors. Tables 1 and 2 present the QRM and TBC publication results, respectively.

\subsection{Comparison process and the classification of the approaches}

Following the Step 3 of the research process, the QRM tactics and their respective approaches are presented in Figure 4 (Suri, 1998, 1999, 2003, 2010a, 2011).

Table 1. Rajan Suri's QRM publications

\begin{tabular}{|c|c|}
\hline Year & Publication's Title \\
\hline 1998 & Quick Response Manufacturing: A Companywide Approach to Reducing Lead Time. \\
\hline 1999 & How QRM takes the way out \\
\hline 2000 & $\begin{array}{l}\text { What Kind of "Numbers" can a Company Expect After Implementing Quick Response } \\
\text { Manufacturing? }\end{array}$ \\
\hline 2003 & $\begin{array}{l}\text { QRM and POLCA: A Winning Combination for Manufacturing Enterprises in the 21st } \\
\text { Century }\end{array}$ \\
\hline 2005 & Filling the Gap \\
\hline 2007 & Manufacturing Critical-path Time (MCT): The QRM Metric for Lead Time \\
\hline 2010 & A quick response for office management \\
\hline 2010 & Go beyond Lean \\
\hline 2010 & It's about time: The competitive Advantage of Quick Response Manufacturing \\
\hline 2011 & Beyond Lean: It's About Time \\
\hline 2015 & $\begin{array}{l}\text { A timely metric: MCT or manufacturing critical-path time, simplifies improvement } \\
\text { opportunities }\end{array}$ \\
\hline & $\begin{array}{l}\text { Source: The authors own } \\
\text { Table 2. George Stalk's TBC publications }\end{array}$ \\
\hline Year & Publication's Title \\
\hline 1988 & Time- The Next Source of Competitive Advantage \\
\hline 1990 & $\begin{array}{l}\text { Competing Against Time - How Time-Based Competition is Reshaping Global } \\
\text { Markets }\end{array}$ \\
\hline 1990 & Redesign your organization for time-based management \\
\hline 1992 & Time-Based Competition and Beyond: Competing on Capabilities \\
\hline 1993 & Japan's Dark Side of Time \\
\hline
\end{tabular}

Source: The authors own

Table 3. Classes of similarity

\begin{tabular}{c|c|l}
\hline \multicolumn{2}{c|}{ Class of similarity } & Description \\
\hline A & Analogous & Similar in terms of action and/or tools and/or methods \\
NA & Not Analogous & Not similar in terms of action and/or tools and/or methods \\
Non & Non-existence & No action and/or tools and/or methods for comparison \\
\hline
\end{tabular}




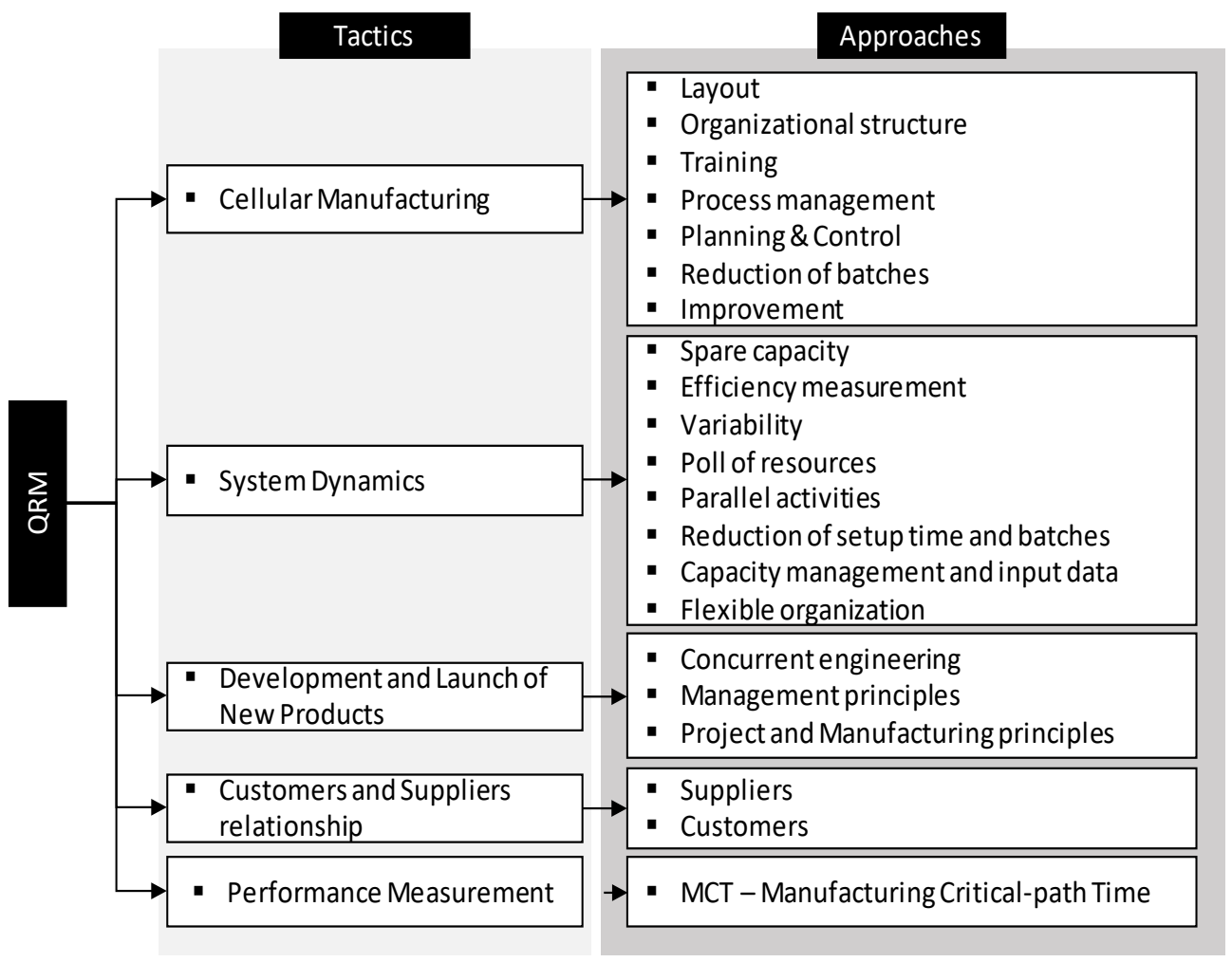

Figure 4. Structure of the QRM tactics

Source: The authors own

\begin{tabular}{|l|l|}
\hline $\begin{array}{l}\text { - Definition of comparison } \\
\text { variables }\end{array}$ & $\rightarrow \begin{array}{l}\text { - Actions, tools and methods proposed } \\
\text { in the approaches }\end{array}$ \\
\hline $\begin{array}{l}\text { - Definition of analysis } \\
\text { criteria }\end{array}$ & $\rightarrow \begin{array}{l}\text { - Qualitative analysis of similarity of } \\
\text { the comparison variables }\end{array}$ \\
\hline - Analysis of similarity & $\begin{array}{l}\text { Classification of similarity between } \\
\text { the approaches }\end{array}$ \\
\hline
\end{tabular}

Figure 5. Comparison process

Source: The authors own

\section{COMPARISON OF THE QRM AND TBC APPROACHES}

In this section, a comparison of the approaches for each tactic used by QRM is presented. Before the comparisons are presented in the tables, an introduction of the tactic in question is made and, just below the tables, the considerations are presented.

\subsection{Cellular Manufacturing}

According to Lin et al. (2012), a selection of the best manufacturing practices is essential for a manufacturing strategy to succeed. The companies with the best practices usually achieve higher manufacturing performance than their competitors.

Suri (1998) presents the seven QRM principles to change a cost-based company into a time-based company, based on the already existing products. The principles refer to the approaches the QRM applies in cellular manufacturing. Cellular manufacturing in QRM is defined as a set of machines arranged to execute the complete job of a product's family in accordance with the operations sequence, which is aimed at minimizing the handling of materials. The changes in the organizational structure from functional to cellular must include the office operations, once it can represent about $50 \%$ of the total lead time (Suri, 1998, 2010a, 2010b). 
According to Stalk (1990a, 1990b), there are two core concepts in TBC: the main sequence and the continuous flow. TBC is structured as one single system focused on a continuous work flow. It invests to reduce the lead time and does not work on bottlenecks. Its approach is to work on the improvement of practices related to the upstream processes to relieve the downstream processes. Table 4 presents the comparison of the approaches for the cellular manufacturing tactic.

Table 4 illustrates the similarity between the approaches. However, the QRM also manages the subject in more detail. During the research process, it was observed that the QRM covers a systemic structure related to cellular manufacturing implementation. Suri (1998) presents seven structured steps to implement the manufacturing cell (Figure 6).

In addition to the seven steps above described, a new method of materials planning is presented, it is called High Level Materials Requirement Planning (HL-MRP) and it is to process/release production orders. Also, a control of materials replenishing is presented; it is called Paired-cell Overlapping Cards with Authorization (POLCA). POLCA combines the pulled and pushed materials planning control.
Suri (2003) presents the disadvantages of a system that is purely pulled or pushed for an environment with a high level of product and/or customized product variability. The dysfunctions are: increase the Working in Progress (WIP) and the lead time, the inability to work with the customized products, and stock proliferation. Braglia et al. (2014) briefly defined POLCA as a hybrid system characterized by multishort cycles of control, where each cycle encompasses two successive work units and they are overlapped two by two.

\subsection{Customer and supplier relationship}

Suri (1998) mentions that the relationship between the customer and the supplier is a duality, because both roles are taken into account by the company in a certain moment and that examining the own behavior is an opportunity to ruminate about improvements.

The approaches are similar in regard to the lead time reduction. The actions in both methodologies drive the company to achieve clear communications with the chain and the involvement of everyone in the process. However, in

Table 4. Comparison of the approaches for the cellular manufacturing tactic

\begin{tabular}{|c|c|c|c|}
\hline Approach & QRM & TBC & Sim \\
\hline Layout & $\begin{array}{l}\text { - Oriented to product and not to center of } \\
\text { technology }\end{array}$ & $\begin{array}{l}\text { - Oriented to product and not to center of } \\
\text { technology }\end{array}$ & $A$ \\
\hline $\begin{array}{l}\text { Organizational } \\
\text { structure }\end{array}$ & $\begin{array}{l}\text { - Elimination of departments, horizontal } \\
\text { structure responsible for the cell } \\
\text { performance }\end{array}$ & $\begin{array}{l}\text { - Reduction of the level of management, } \\
\text { delegating authority to the team } \\
\text { responsible for the job }\end{array}$ & $A$ \\
\hline Training & $\begin{array}{l}\text { - Cross training for the cell members - } \\
\text { focus on flexibility and not dependency } \\
\text { of a single member within the cell }\end{array}$ & $\begin{array}{l}\text { - Cross training for the team - focus on } \\
\text { flexibility and wide vison of the process }\end{array}$ & $A$ \\
\hline $\begin{array}{l}\text { Process } \\
\text { management }\end{array}$ & $\begin{array}{l}\text { - End to end process management } \\
\text { instead top down management - focus on } \\
\text { creation of continuous flow }\end{array}$ & $\begin{array}{l}\text { - Focus on elimination of departments to } \\
\text { create a continuous work flow }\end{array}$ & $A$ \\
\hline $\begin{array}{l}\text { Planning \& } \\
\text { Control }\end{array}$ & $\begin{array}{l}\text { - Replace the complex and centralized } \\
\text { scheduling and planning system for a } \\
\text { simple and local procedure managed } \\
\text { within the cell }\end{array}$ & $\begin{array}{l}\text { - Decentralized, the team is responsible } \\
\text { for the job, implementation of solutions } \\
\text { as soon as a problem is identified }\end{array}$ & A \\
\hline $\begin{array}{l}\text { Reduction of } \\
\text { batches }\end{array}$ & $\begin{array}{l}\text { - With the machines arranged close one } \\
\text { of each other there is no need to } \\
\text { complete a batch to change the parts to } \\
\text { the next operation }\end{array}$ & $\begin{array}{l}\text { - Reduce batches to increase the } \\
\text { frequency of complete mix of products } \\
\text { and respond faster to the client }\end{array}$ & $A$ \\
\hline Improvement & $\begin{array}{l}\text { - Chase batches reduction even more } \\
\text { every time while improves quality and } \\
\text { reduces wastes in combination with } \\
\text { Kaizens }\end{array}$ & $\begin{array}{l}\text { - With the layout focused on product, the } \\
\text { communication flow is fast in all } \\
\text { direction (horizontal and vertical) what } \\
\text { stimulate continuous improvement and } \\
\text { encourage employees to contribute with } \\
\text { suggestions }\end{array}$ & $A$ \\
\hline
\end{tabular}




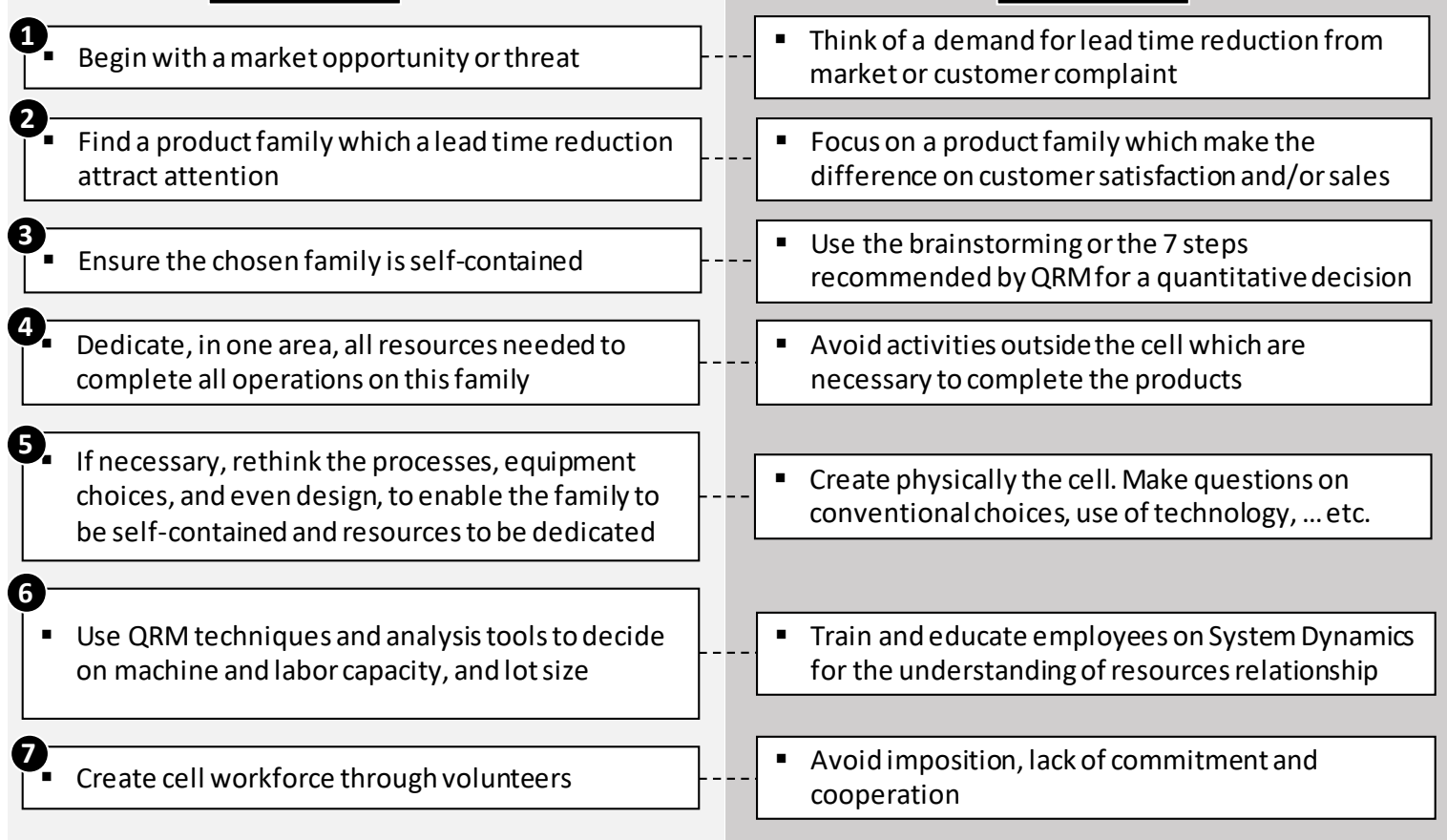

Figure 6. Seven QRM steps to implement the cellular manufacturing tactic Source: Compiled from Suri (1998).

addition to questions related to customer and supplier relationships, the QRM also covers the topics of making or buying decisions and QRM principle training for buyers.

Stalk et Hout (1990b) mention two practices: planning synchronization and capacity leveling in the supplier relationship. Carter et al. (1995) present the TBC fundamental strategies, including simplification, parallel activities and extra resources. Such practices are presented in detail in Suri's (1998) System Dynamics chapter. This article presents the approaches related to the system dynamics tactic in Subsection 3.4. It is worth mentioning that Suri (1998) presents the system dynamics principles in a context of shop floors and office activities. In the customer and supplier relationship in Table 5, educating customers and suppliers about the QRM program is recommended.

\subsection{Development and launch of new products}

Carter et al. (1995) stated that time-based competitors can be divided into two categories: 1) Fast to Product; and 2) Fast to Market. The second refers to the competitor's capacity to launch new products in the market faster than its competitors. Suri (1998) mentions that a vast amount of literature regarding the development and launching of new products exists. In addition, the QRM approaches it in regard to the application of the QRM techniques and prin- ciples to reduce the time of the development process, instead of the methodology itself. Based on this information, the comparison between the methodologies was carried out (Table 6).

The comparison reveals that both methodologies not managing the product development itself, but instead managing the practices to accelerate the process. None of the TBC and QRM publications used in this article mention the development process of new products; they only mention practices to reduce the development time. Within the context proposed by both methodologies, it was noted that the management principles approach is similar between the methodologies. The conceptual approach is also highlighted more than the methodological approach for this tactic.

In regards to the organizational and system dynamic principles, QRM provides more detail. It also provides its own concept, Focused Target Market Segment (FTMS), as a drive to develop and launch new products. In regards to design and manufacturing principles, QRM presents the techniques as a DFM (Design for Manufacturing) and DFA (Design for Assembly). QRM also presents the possibility of extending the concept "Design For" to other criteria, called DFX, where " $X$ " can be the quality, testability, reliability or another desired outcome. The interaction of the bill of materials, as well as other topics, was not mentioned in TBC. Therefore, no similarities between the methodologies existed. 
Table 5. Comparison of the approaches for the customer and supplier relationship tactic

\begin{tabular}{|c|c|c|c|}
\hline Approach & QRM & TBC & Sim \\
\hline $\begin{array}{l}\text { Customer and } \\
\text { Supplier }\end{array}$ & $\begin{array}{l}\text { - Choose suppliers based on price and } \\
\text { ability to delivery with quality. Include } \\
\text { supplier distance as an evaluation factor } \\
\text { - Establish long term partnership with a } \\
\text { few suppliers } \\
\text { - Educate suppliers to implement QRM } \\
\text { - Educate customers on QRM program, } \\
\text { explain the benefits of lot reduction } \\
\text { - Educate the procurement staff on QRM } \\
\text { bases and challenge "make or buy" } \\
\text { decisions } \\
\text { - Use lead time reduction as a main } \\
\text { supplier performance indicator } \\
\text { - Invest on supplier improvement } \\
\text { - Create learning system for suppliers in } \\
\text { order to support company needs } \\
\text { - Delegate POU (Point Of Use) } \\
\text { responsibility to supplier } \\
\text { - Reserve capacity instead of orders for } \\
\text { specific parts } \\
\text { - Share forecast and process planning } \\
\text { with suppliers } \\
\text { - Do not wait for complete loaded trucks } \\
\text { to transport the products } \\
\text { - Outsource transportation services, } \\
\text { focus on core business } \\
\text { - Work with designers and engineers } \\
\text { from customers } \\
\text { - Work with the entire chain }\end{array}$ & $\begin{array}{l}\text { - Few suppliers with long term } \\
\text { relationship } \\
\text { - Share demand forecast for launching } \\
\text { new products } \\
\text { - Include suppliers on information } \\
\text { system in order to define stock policies } \\
\text { together } \\
\text { - Involvement of the entire chain to } \\
\text { overcome the inertia of the chain, not } \\
\text { only the final supplier } \\
\text { - Expose the benefits to be time-based } \\
\text { - Time compression on supply chain has } \\
\text { to be done in pair or groups of companies } \\
\text { instead of isolated by each company. The } \\
\text { objective is to reduce stock buffers } \\
\text { - Share long, medium and short terms } \\
\text { planning with the supply chain } \\
\text { - Work in parallel together suppliers, any } \\
\text { change on product must be } \\
\text { communicated in order to the supplier } \\
\text { be able to meet on time the new } \\
\text { demand } \\
\text { - Synchronization of the lead time } \\
\text { through standardization and parallel } \\
\text { activities / capacity leveling } \\
\text { - Programs of development should be } \\
\text { planned locally }\end{array}$ & A \\
\hline
\end{tabular}

Source: The authors own

\subsection{System Dynamic}

Godinho et Uzsoy (2009) mentioned that just a few applications of system dynamics in manufacturing systems exist, even with the evidence of the potential advantages of this technique. Suri (1998) states that failures in lead time reductions by companies are related to the lack of usage of the system dynamics, management mindset and obsolete performance measurements.

For capacity management, input data control and the pool of resources approaches, no similarities existed between the methodologies. The TBC articles do not discuss both approaches. Thus, a comparison against the QRM approaches was not possible.

Both methodologies mention flexible organization. Stalk (1988) states that flexible factories allow for the produc- tion of a greater variety of products at a lower cost, when compared to traditional companies. Trade-offs between scale and variety were made. However, differences were observed between the proposed actions. QRM did clearly explore the use of flexibility among the cells, while TBC did not. It is worth mentioning that Bozarth et Chapman (1995) stated that the ad-hoc technique is used in TBC, with the aim of creating capability in the process to generate temporary solutions to solve demand issues.

\subsection{Performance Management}

Suri (2015) stated that management needs to clearly define the lead time, because many definitions on this term exist. Therefore, it is necessary to have a good understanding of it in order to reduce it. Suri (2010a) presents a performance measurement system used by QRM, the MCT (Man- 
Table 6. Comparison of the approaches for development and launch of new products tactic

\begin{tabular}{|c|c|c|c|}
\hline Approach & QRM & TBC & Sim \\
\hline $\begin{array}{l}\text { Concurrent } \\
\text { engineering }\end{array}$ & $\begin{array}{l}\text { - Multitdisciplinary team integrated in } \\
\text { product development process - } \\
\text { involvement of all areas from design to } \\
\text { sales } \\
\text { - Use Kaizen concept to understand the } \\
\text { process before improve it }\end{array}$ & - Multidisciplinary development team & NA \\
\hline $\begin{array}{l}\text { Management } \\
\text { principles }\end{array}$ & $\begin{array}{l}\text { - Establish the sense of urgency, create a } \\
\text { timeline for product development } \\
\text { - Use Project Management methods and } \\
\text { Critical-Path } \\
\text { - Control project scope } \\
\text { - Promote short interactions more often } \\
\text { instead of long meetings and discussions } \\
\text { sessions } \\
\text { - Use virtual organizations - collaboration } \\
\text { improves competition } \\
\text { - Establish lessons learned and } \\
\text { recommendations for next projects } \\
\text { - Involve suppliers and customers in the } \\
\text { process, understand suppliers capability } \\
\text { for new demands }\end{array}$ & $\begin{array}{l}\text { - There are few management revisions. } \\
\text { The management role is to support and } \\
\text { ensure resources } \\
\text { - Time is the key variable } \\
\text { - Use benchmarking } \\
\text { - Project managed and executed by } \\
\text { experienced teams empowered to make } \\
\text { decisions } \\
\text { - Projects planned in phases: Planning } \\
\text { and Preparation; Product Definition; } \\
\text { Project Development; Increasing of } \\
\text { Productivity Capacity; Product } \\
\text { Improvement } \\
\text { - The planning seeks forecast all } \\
\text { uncertainties } \\
\text { - Freezing of product specification } \\
\text { - Promote institutional learning } \\
\text { - Use Information Technology } \\
\text { - Involve suppliers and customers in the } \\
\text { development process }\end{array}$ & A \\
\hline $\begin{array}{l}\text { Design and } \\
\text { manufacturing } \\
\text { principles }\end{array}$ & $\begin{array}{l}\text { - Determine architecture and platform } \\
\text { - Use QFD to identify product critical } \\
\text { attributes, desirable characteristics, } \\
\text { positioning compared against the } \\
\text { competitors and highlight the } \\
\text { interactions among the different } \\
\text { engineering characteristics } \\
\text { - Use as many as possible parts already } \\
\text { designed } \\
\text { - Explore interactions between product } \\
\text { design and bill of material - delay as } \\
\text { much as possible the conclusion of } \\
\text { product which in a certain previous stage } \\
\text { of its conclusion can be transformed in } \\
\text { other product } \\
\text { - Use lead time as a driver of product } \\
\text { platform and strategy of differentiation } \\
\text { for delay } \\
\text { - Use prototyping } \\
\text { - Apply "Desig For" techniques } \\
\text { - Apply project analysis (thermal, stress, } \\
\text {...etc) } \\
\text { - Invest on manufacturing process } \\
\text { development in advance }\end{array}$ & $\begin{array}{l}\text { - Manufacturing and Development areas } \\
\text { are involved along all project } \\
\text { - Support activities are not included in } \\
\text { main development flow }\end{array}$ & Non \\
\hline $\begin{array}{l}\text { Organizational } \\
\text { and system } \\
\text { dynamics } \\
\text { principles }\end{array}$ & $\begin{array}{l}\text { - Apply FMTS (Focused Market Target } \\
\text { Segment) concept } \\
\text { - Build multidisciplinary teams } \\
\text { - Allocate the team together physically } \\
\text { - Eliminate non-added value activities } \\
\text { - Plan idle capacity } \\
\text { - Evaluate capacity of executing } \\
\text { development projects simultaneously } \\
\text { - Use pool of resources concept } \\
\text { - Apply overlapping of activities in the } \\
\text { development process }\end{array}$ & $\begin{array}{l}\text { - The team is allocated physically } \\
\text { together } \\
\text { - New Programs are generated } \\
\text { continuously } \\
\text { - Execute parallel / overlapping activities }\end{array}$ & NA \\
\hline
\end{tabular}


Table 7. Comparison of the approaches for the system dynamic tactic

\begin{tabular}{|c|c|c|c|}
\hline \multicolumn{4}{|c|}{ System Dynamics } \\
\hline Approach & QRM & TBC & Sim \\
\hline Idle capacity & $\begin{array}{l}\text { - Use system modeling to determine the } \\
\text { Idle capacity needed }\end{array}$ & - Plan using excess of resources & A \\
\hline $\begin{array}{l}\text { Efficiency } \\
\text { measurement }\end{array}$ & $\begin{array}{l}\text { - Measure efficiency as being the lead } \\
\text { time reduction }\end{array}$ & - Time is the performance driver & A \\
\hline Variability & $\begin{array}{l}\text { - Eliminate the dysfunctional variability } \\
\text { - Standardize procedures } \\
\text { - Standardize documentation and } \\
\text { activities flow } \\
\text { - Eliminate rework } \\
\text { - Separate complex jobs from simple jobs } \\
\text { - Regularize input data through the } \\
\text { control of upstream processes } \\
\text { - Use periodic work or routine to relieve } \\
\text { workload out of control }\end{array}$ & $\begin{array}{l}\text { - Focus on predictability of the processes } \\
\text { - Work on regularization of upstream } \\
\text { processes }\end{array}$ & NA \\
\hline Pool of resources & $\begin{array}{l}\text { - Make the resources flexible to server a } \\
\text { common queue instead dedicated } \\
\text { resources serving multiple queues } \\
\text { - Redesign activities to enable flexibility }\end{array}$ & & I \\
\hline Parallel activities & $\begin{array}{l}\text { - Convert sequential activities in parallel } \\
\text { activities }\end{array}$ & $\begin{array}{l}\text { - Convert sequential activities in parallel } \\
\text { activities }\end{array}$ & A \\
\hline $\begin{array}{l}\text { Reduce setup } \\
\text { time and lot size }\end{array}$ & $\begin{array}{l}\text { - Use technology to reduce setup time } \\
\text { and promote discussions aimed to } \\
\text { solutions - Reducing setup time implies } \\
\text { on lot size reduction } \\
\text { - Focus on work flow mindset instead } \\
\text { traditional performance measurement }\end{array}$ & $\begin{array}{l}\text { - Invest to reduce time } \\
\text { - Layout based on proximity of the } \\
\text { machines to encourage lot size reduction }\end{array}$ & A \\
\hline \begin{tabular}{|l|} 
Capacity \\
management and \\
input data \\
control
\end{tabular} & $\begin{array}{l}\text { - Use Little's Law } \\
\text { - Explore flexibility }\end{array}$ & & I \\
\hline $\begin{array}{l}\text { Flexible } \\
\text { organization }\end{array}$ & $\begin{array}{l}\text { - Explore flexibility among the cells } \\
\text { - Use floating resources among the cells } \\
\text { - Use vertical migration for seasonal } \\
\text { demands } \\
\text { - keep trained employees on complex } \\
\text { activities, but that in regular demands } \\
\text { execute activities less complex }\end{array}$ & $\begin{array}{l}\text { - Focus on one single system and main } \\
\text { sequence of activities (which add value) } \\
\text { - Explore multidisciplinary teams } \\
\text { - Use ad-hoc resources }\end{array}$ & NA \\
\hline
\end{tabular}


Table 8. Comparison between the approaches of the performance measurement tactic

\begin{tabular}{|c|c|c|c|}
\hline Approach & QRM & TBC & Sim \\
\hline MCT & $\begin{array}{l}\text { - Defined as the quantity of calendar days } \\
\text { from customer request to deliver the } \\
\text { first part } \\
\text { - The MCT quantifies the waste in whole } \\
\text { organization, provides understanding on } \\
\text { macro system and extends it to the } \\
\text { supply chain }\end{array}$ & $\begin{array}{l}\text { - The TBC has its performance } \\
\text { measurement based on time and } \\
\text { presents the performance indicators for } \\
\text { different tactics: } \\
\text { Development of New Products } \\
\text { - Time from idea to market } \\
\text { - Rate of new products introduced } \\
\text { - Percentage first competitor to market } \\
\text { Production } \\
\text { - Value added as percentage of total } \\
\text { elapsed time } \\
\text { - Uptime Vs Yield } \\
\text { - Inventory turnover } \\
\text { - Cycle time } \\
\text { Decision Making } \\
\text { - Decision cycle time } \\
\text { - Time lost waiting for decisions } \\
\text { Response Time } \\
\text { - Quoted lead time } \\
\text { - Percentage deliveries on time } \\
\text { - Timefrom customer need and delivery }\end{array}$ & A \\
\hline
\end{tabular}

Source: The authors own

Table 9. Classification of similarity

\begin{tabular}{|l|c|c|c|c|c|c|c|}
\hline \multicolumn{1}{|c|}{ Tactics } & Analogous & $\begin{array}{c}\text { Not } \\
\text { Analogous }\end{array}$ & $\begin{array}{c}\text { Non- } \\
\text { existent }\end{array}$ & Total & \% A & \%NA & \%I \\
\hline Cellular Manufacturing & 7 & 0 & 0 & 7 & $100 \%$ & $0 \%$ & $0 \%$ \\
\hline $\begin{array}{l}\text { Customers and Suppliers } \\
\text { Relationship }\end{array}$ & 1 & 0 & 0 & 1 & $100 \%$ & $0 \%$ & $0 \%$ \\
\hline $\begin{array}{l}\text { Development and Launch of new } \\
\text { Products }\end{array}$ & 1 & 3 & 0 & 4 & $25 \%$ & $75 \%$ & $0 \%$ \\
\hline System Dynamic & 4 & 1 & 3 & 8 & $50 \%$ & $13 \%$ & $38 \%$ \\
\hline Performance Measurement & 1 & 0 & 0 & 1 & $100 \%$ & $0 \%$ & $0 \%$ \\
\hline Total per class of similarity & $\mathbf{1 4}$ & $\mathbf{4}$ & $\mathbf{3}$ & $\mathbf{2 1}$ & &
\end{tabular}

Source: The authors own

ufacturing Critical-path Time), previously called the QRM number (Suri, 1998). Ericksen et al. (2007) present a detailed explanation of the phrases defined in MCT.

TBC literature has explored the performance indicator in depth and the concept between the methodologies is considered analogous, when the main indicator is time. Tubino et Suri (2000) present a set of metrics based on the general rules to allow companies to measure benefits by reducing the lead time. Ericksen et al. (2005) relate the MCT to quality, price and delivery in relation to the supply chain. They illustrate the variations in the performance indicators, based on the needs to measure it according to the organization strategy. In his article entitled, "A Timely Metric," Suri (2015) presents an overview of MCT, explaining how it quantifies the system wide waste and displays all the improvement opportunities.

\section{RESULTS}

As previously presented in Table 3 in this article, a classification of similarity has been created. For each tactic used by QRM, 
the list of approaches was structured and compared against the approaches used by TBC. The data were then compiled to verify the distribution of each class of similarity (Table 9).

The approaches for tactics: cellular manufacturing, customer and supplier relationship and performance measurement reached the maximum level of similarity between the methodologies. Suri (1998) and Stalk et Hout (1990a), in reference to cellular manufacturing, presented actions that drive the company to create a non-departmental structure, emphasizing that departments create barriers. These authors present concepts that overcome these barriers. In regards to the customer and supplier relationship, Willis (1998) mentions that the relationship with suppliers should be based on a partnership and that a company cannot allow its responsiveness to be impaired by inefficiency or lack of collaboration from a supplier.

Inman (1992) mentions that suppliers play a team member role, by contributing with their abilities. Suri (1998) and Stalk et Hout (1990a), in the sense of partnership, state that a long term relationship with suppliers involving the entire chain should be established. Birtwistle et al. (2006) corroborate that quick response strategies are dependent on building long term relationships, sharing information and investing in technology and facilities with suppliers. In regards to performance measurement, Suri (1998) and Stalk et Hout (1990a) declare time as the main metric to be measured. Godinho et Veloso (2013) state that TBC and QRM are focused on competitiveness based on time. As a consequence, the lead time, as a performance measurement, is critical for both methodologies.

For the tactic of developing and launching new products, both methodologies have different practices (referred to Section 3.3). None of the TBC and QRM publications used in this study presented a process to develop and launch new products. Instead, they presented practices to reduce the time of the already established processes. Suri (1998) suggests the application of "Design For" techniques and presents the FTMS as a driver for focusing on potential products to be developed or modified. TBC publications focus more on principles.

Stalk et Hout (1990b) present the methods that do not work, mentioning that fast innovators use the same techniques that flexible manufacturers do (e.g., lot size, planned smaller improvements, but more of them and flow). They consider allocating all needed resources together for the development process. Similarly, Carter et al. (1995) focus on introducing new products as a strategy and Willis (1998) as one of four competitive requirements. Blackburn (1991) affirms that the process varies across companies. Hence, it is more difficult to track a development process, than a manufacturing process.
The higher percentage of the non-existence of similarity is related to the system dynamic tactic. More specifically, Suri (1998) states that, among the approaches, the pool of resources and capacity management and the input data control have actions focused on flexibility. TBC focuses on flexibility. Willis (1998) mentions flexibility as the essence of TBC. And Stalk et Hout (1990b) present the concepts used for flexible manufacturers (e.g., lot size, flow, scheduling, resource capacity lead time and productivity). In the publications reviewed in this article, none of them found actions or processes that allowed for the comparison of actions proposed by QRM in regards to these two approaches. Overall, twenty-one approaches, divided into five tactics, were compared. The distribution of similarity is presented in Figure 7.

\section{Analogous Not Analogous 『 Non-Existence}

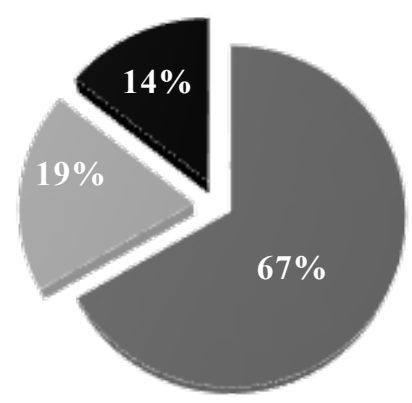

Figure 7. Distribution of classes of similarity Source: The authors own

\section{CONCLUSIONS}

The primary objective of this article was to compare the similarity between the QRM and TBC methodologies. The results reveal that the methodologies are similar; the approaches are $100 \%$ similar to three. Only $14 \%$ of the approaches presented the non-existence of similarities. For the approaches classified as Not Analogous, the higher percentage was related to the development and launching of new products. Neither of the methodologies mentions or presents new methods. Instead, they present practices to accelerate the processes already defined to develop new products. In addition, a theoretical evolution from TBC to QRM exists. A greater emphasis on materials planning and control in QRM exists. The use of system dynamics in the manufacturing industry was also emphasized. QRM adds more context on time-based subjects, presenting methods that were not explored by TBC.

This article contributes to the literature in relation to a better understanding in terms of the concepts of competition based on time as a source of competitive advantage. 
Brazilian Journal of Operations \& Production Management

Volume 14, Número 3, 2017, pp. 414-427

DOI: 10.14488/BJOPM.2017.v14.n3.a14
This article also discusses the set of practices that the previous researchers have studied and discussed. As already mentioned, the boundaries of this research lie in the analysis of the QRM and TBC publications. These publications are related to tactics and approaches used to change companies that compete based on cost to companies that compete based on time. In this sense, it provides a framework that companies can use to evaluate the differences of their practices against time-based practices. It is recommended that future research compare practical applications in order to identify how efficiently the methodologies supported companies to develop competitive advantages.

\section{REFERENCES}

Birtwistle, G., Fiorito, S. S. and Moore, C. M. (2006), "Suppliers Perception of Quick Response Systems", Journal of Enterprise Information Management, Vol. 19, No. 3, pp. 334345.

Blackburn, J. (1991), Time Based-Competition: The Next Battle Ground in American Manufacturing, Business One Irwin, Homewood, IL.

Blackburn, J. (1992), "Time-Based Competition White-Collar Activities", Business Horizons, Vol. 35, No. 4, pp. 66.

Bozarth, C. et Chapman, S. (1995), "A Contingency View of Time-Based Competition for Manufacturers", International Journal of Operations \& Production Management, Vol. 16, No. 6, pp. 56-67.

Braglia, M., Castellano, D. and Frosolini, M. (2014), “Optimization of POLCA-Controlled Production Systems with a Simulation-Driven Genetic Algorithm", International Journal of Advanced Manufacturing Technology, Vol. 70, pp. 385-395.

Carter, P., Melnyk, S. and Handfield, R. (1995), "Identifying the Basic Process Strategies for Time-Based Competition", Production and Inventory Management Journal, Vol. 36, No. 1, pp. 65-70.

Emboava, F. et Cardoso, R. (2016), “Um Estudo Sobre as Relações dos Conceitos e Princípios do Lean Manufacturing e Time-Based Competition com os Princípios do QRM - Quick Response Manufacturing", paper presented at the XXIII SIMPEP 2016: Symposium of Production Engineering, Bauru, SP, 8-10 November 2016, available at: http://www.simpep.feb. unesp.br/anais_simpep.php?e=11 (Accessed on 15 December 2016).

Ericksen, P., Stoflet, A. and Suri, R. (2007), "Manufacturing Critical-path Time (MCT): The QRM Metric for Lead Time", Technical Report, Center for Quick Response Manufacturing, University of Wisconsin-Madison.

Ericksen, P., Suri, R. and El-Jawhari, B. and Armstrong, A. J. (2005), "Filling the Gap", APICS Magazine.
Fachin, O. (2006), Fundamentos de Metodologia, 5 ed., Saraiva, São Paulo, SP.

Filipowska, A., Kaczmarek, M, Kowalkiewicz, M. et al. (2009), "Procedure and Guidelines for Evaluation of BPM Methodologies", Business Process Management Journal, Vol. 15, pp. $336-357$.

Gerhardt, T.E. et Silveira, D.T. (2009), Métodos de Pesquisa, 1 ed., Editora UFRGS, Porto Alegre, RS.

Gil, A. (2008), Como Elaborar Projetos de Pesquisa, 4 ed., Atlas, São Paulo, SP.

Godinho F. M. et Uzsoy, R. (2009), "Efeito da Redução do Tamanho do Lote e de Programas de Melhoria Contínua no Estoque em Processo (WIP) e na Utilização: Estudo Utilizando uma Abordagem Híbrida System Dynamics - Factory Physics", Produção, Vol. 19, No. 1, pp.214-229.

Godinho F. M. et Veloso, S.E. (2013), “From Time-Based Competition (TBC) to Quick Response Manufacturing (QRM): The Evolution of Research Aimed at Lead Time Reduction", The International Journal of Advanced Manufacturing Technology, Vol. 64, pp. 1177-1191.

Helms, M.M. et Ettkin, L.P. (2000), “Time-Based Competitiveness: A Strategic Perspective", Competitiveness Review, Vol. 10, No. 2, pp. 1-14.

Hum, S.H. et Sim, H.H. (1996), "Time-Based Competition: Literature Review and Implications for Modelling", International Journal of Operations \& Production Management, Vol. 16, pp. $75-90$.

Inman, R.A. (1992), "Time-Based Competition: Challenges for Industrial Purchasing", Industrial Management, Vol. 34, No. 2, pp. 31-33.

Kauark, F.S., Manhães, F.C. and Medeiros, C.H. (2010), Metodologia de Pesquisa: Um Guia Prático, 1 ed., Via Litterarum, Itabuma, BA.

Lin, Y., Ma, S. and Zhou. L. (2012), “Manufacturing Strategies for Time Based Competitive Advantages", Industrial Management \& Data System, Vol. 112, No. 05, pp. 729-747.

Morgan, G. et Smircich, L. (1980), "The Case for Qualitative Research", Academy of Management, Vol. 5, No. 04, pp. 491500.

Stalk, G. (1988), "The Next Source of Competitive Advantage", Harvard Business Review, pp. 41-51.

Stalk, G. (1992), "Time-Based Competition and Beyond: Competing on Capabilities", Conference Executive Summary, pp. 27-29.

Stalk, G. et Hout, T.M. (1990a), “Redesign Your Organization for Time-Based Management", Planning Review, Vol. 18, pp. 4-9. 
Stalk, G. et Hout, T.M. (1990b), Competing Against Time: How Time-Based Competition is Reshaping Global Markets, 1 ed., Free Press, New York, NY.

Stalk, G. et Webber, A.M. (1993), “Japan's Dark Side of Time", Harvard Business Review, pp. 93-102.

Suri, R. (1998), Quick Response Manufacturing: A Companywide Approach to Reducing Lead Time, 1 ed., Productivity Press, Portland, OR.

Suri, R. (1999), “How QRM Takes the Wait Out”, Journal for Quality \& Participation, pp. 46-49.

Suri, R. (2003), "QRM and POLCA: A Winning Combination for Manufacturing Enterprises in the 21st Century", Technical Report, Center for Quick Response Manufacturing, University of Wisconsin-Madison.

Suri, R. (2010a), It's About Time: The Competitive Advantage of Quick Response Manufacturing, 1 ed., Productivity Press, New York, NY.

Suri, R. (2010b), "A Quick Response to Office Management", Industrial Management, pp. 25-30.
Suri, R. (2010c), “Going Beyond Lean”, Industrial Engineering, pp. 30-35.

Suri, R. (2011), "Beyond Lean: It's About Time”, Technical Report, Center for Quick Response Manufacturing, University of Wisconsin-Madison.

Suri, R. (2015), “A Timely Metric: MCT or Manufacturing Critical-path Time, Simplifies Improvement Opportunities", Industrial Engineering, pp. 36-41.

Tubino, F. et Suri, R. (2000), "What Kind of "Numbers" Can a Company Expect After Implementing Quick Response Manufacturing?", paper presented at: QRM 2000 Conference Proceeding, Society of Manufacturing Engineers Press, Dearborn, MI, pp. 943-972.

Willis, T. H. (1998), “Operational Competitive Requirements for the Twenty-First Century", Industrial Management \& Data Systems, Vol. 2, pp. 83-86. 